\title{
Borderline Breast Phyllodes Tumor
}

National Cancer Institute

\section{Source}

National Cancer Institute. Borderline Breast Phyllodes Tumor. NCI Thesaurus. Code C5316.

A phyllodes tumor of the breast characterized by the presence of intermediate features and a stroma which usually resembles low grade fibrosarcoma. 